\title{
UKRAIŃSKIE KARY W PRAWIE KARNYM W PRZEKŁADZIE NA JEZZYK POLSKI
}

\author{
Katarzyna LITWIN, mgr, Lukasz RACHTAN, mgr \\ Katedra Prawa Karnego Instytutu Wymiaru Sprawiedliwości, \\ Krakowska Akademia im. A. F. Modrzewskiego \\ ul. Żeromskiego 5/8, 35-001 Rzeszów \\ ukrainski@litwin.rzeszow.pl
}

\begin{abstract}
Abstrakt: Sąsiedztwo Polski i Ukrainy, rozwijająca się współpraca, również w zakresie pomocy prawnej pomiędzy organami wymiaru sprawiedliwości, powoduje rosnące zapotrzebowanie na tłumaczenia tekstów prawnych $\mathrm{z}$ dziedziny prawa karnego. Ze względu na brak pomocy naukowych poruszających problematykę ukraińskiej terminologii prawniczej, w tym systemu kar Ukrainy, tłumacz stoi przed trudnym wyzwaniem polegającym na badaniu aktów prawnych obu państw, ich interpretacji i wyborze ostatecznego wariantu tłumaczenia. Niniejsze opracowanie stanowi omówienie dwunastu rodzajów kar, przewidzianych w prawie karnym Ukrainy, w kontekście problematyki tłumaczenia tekstów prawnych na język polski. Zestawiając przepisy ukraińskie i polskie, dotyczące różnorodnych gałęzi prawa, wyjaśnione zostały kwestie problematyczne w procesie tłumaczenia ukraińskich terminów dotyczących kar kryminalnych, a także przedstawione zostały propozycje ich prawidłowego przekładu.
\end{abstract}

\section{TRANSLATION OF UKRAINIAN CRIMINAL PENALTIES INTO POLISH}

\begin{abstract}
The bonds between Ukraine and Poland, developing collaboration also within the framework of mutual legal assistance between justice departments cause growing demand for legal translations in the field of criminal law. The absence of legal dictionaries and academic papers about Ukrainian legal terminology and the system of penalties in Ukraine leads to difficulties connected with providing equivalents by comparing parallel texts of statutes of these two countries. This paper analyses twelve types of penalties, regulated by criminal law of Ukraine, in the context of translation problems encountered in Ukrainian-Polish translation of legal texts. After presenting a brief comparison of Ukrainian and Polish regulations in different fields of law, the authors discuss the problematic issues connected with translation of the Ukrainian names of penalties, and also provide recommendations how to translate those terms effectively.
\end{abstract}

\section{Wykaz skrótów:}

k.k. - Ustawa z dnia 6 czerwca 1997 r. Kodeks karny (Dz.U. nr 88 poz. 553).

KKU - Kryminal'nyj kodeks Ukraïny (VVR 2001, N 25-26, st. 131).

k.k.w. - Ustawa z dnia 6 czerwca 1997 r. Kodeks karny wykonawczy (Dz.U. nr 90 poz. 557).

KVKU - Kryminal'no-vykonavčyj kodeks Ukraïny (VVR 2004, N 3-4, st. 21). 


\section{Wstęp}

W dniu 24 maja 1993 roku podpisano w Kijowie Umowę między Rzeczypospolitą Polską a Ukrainą o pomocy prawnej i stosunkach prawnych w sprawach cywilnych i karnych. $\mathrm{Na}$ podstawie tej umowy polskie oraz ukraińskie sądy i prokuratury udzielają sobie wzajemnej pomocy prawnej poprzez sporządzanie, przesyłanie i doręczanie dokumentów, a także poprzez dokonywanie przeszukań, odbieranie i wydawanie dowodów rzeczowych, opracowywanie opinii, dokonywanie oględzin, przesłuchiwanie stron, świadków, biegłych, podejrzanych, oskarżonych, a także przez dokonanie innych czynności procesowych, opisywanych następnie w odpowiedzi na wniosek. W paragrafie 5 omawianej umowy strony zaznaczyły również, że wnioski sporządza się w języku strony wzywającej, dołączając tłumaczenie na język urzędowy strony wezwanej. Rozwój tej współpracy powoduje zatem wzrost znaczenia translatoryki, a w jej ramach problematyki przekładu, którego przedmiotem są obce akty prawne i teksty prawnicze.

W paragrafie 56 Umowy strony przewidziały treść i formę wniosku, określając wymóg dołączenia do wniosku w sprawach karnych opisu i kwalifikacji prawnej popełnionego przestępstwa oraz tekstu przepisów prawa karnego. Tymczasem przepisy wszystkich artykułów części szczególnej Kodeksu karnego zarówno Polski, jak Ukrainy, zawierają nazwy kar kryminalnych. Terminologia powiązana z karami kryminalnymi pojawia się więc w każdym wniosku o pomoc prawną w sprawie karnej lub odpowiedzi na niego, tymczasem w polskiej terminologii prawnej brakuje ekwiwalentów kar ukraińskich. Dlatego prawidłowe przetłumaczenie kar kryminalnych wymaga znajomości nie tylko samego języka, ale również pewnych aspektów ustawodawstwa Ukrainy. Dogłębne przeanalizowanie używanych przez ustawodawcę pojęć prawnych w systemie kar, ustalenie treści i znaczenia odpowiadających tym pojęciom terminów jest podstawą prawidłowego przetłumaczenia na język polski dokumentów ukraińskich, a tym samym zapewnia prawidłowe działanie polskiego wymiaru sprawiedliwości $\mathrm{w}$ kontaktach z Ukrainą.

\section{System kar kryminalnych w ustawodawstwie Ukrainy}

Przewidziane przez ustawodawstwo karne Ukrainy poszczególne rodzaje kar, tworzą pewien ich system, przewidziany w st. 51 KKU. Stanowi on zamknięty katalog kar kryminalnych, a co za tym idzie jedyną podstawę prawną, na której ustawodawca opiera formułowanie sankcji dla wszystkich przestępstw przewidzianych w prawie ukraińskim. Ustawodawstwo Ukrainy przewiduje obecnie 12 rodzajów kar kryminalnych ${ }^{62}$, w tym kar zasadniczych i dodatkowych, stanowiących w pewnym zakresie ekwiwalent polskich kar i środków karnych.

\section{Štraf}

Pierwszym wskazanym w ustawie rodzajem kary kryminalnej jest štraf. Jak podaje Velykyj encyklopedyčnyj jurydyčnyj slovnyk (Šemšučenko 2007, 975) termin ten pochodzi od niemieckiego Strafe, oznaczającego tyle co 'kara'. Zgodnie z ustawodawstwem Ukrainy kara określana mianem štraf polega na tym, że w przypadkach i granicach określonych w Części szczególnej KKU (st. 53 § 1) sąd nakłada na skazanego obowiązek

\footnotetext{
${ }^{62}$ Dla porównania warto przypomnieć, że w Polsce Kodeks karny przewiduje 5 rodzajów kar i 10 środków karnych.
} 
wpłacenia do budżetu państwa określonej kwoty pieniężnej. Jak wynika z definicji, ukraiński štraf (za wyjątkiem różnic polegających na sposobie wymierzania czy wysokości uiszczanej kwoty pieniężnej) jest odpowiednikiem polskiej kary grzywny, wymierzanej na podstawie art. 32 pkt. 1 Kodeksu karnego obowiązującego w Polsce.

\section{Pozbavlennâ vijs'kovogo, special'nogo zvannâ, rangu, čynu abo kvalifikacijnogo klasu}

Pozbavlennâ vijskovogo, specialnogo zvannâ, rangu, čynu abo kvalifikacijnogo klasu, należałoby przetłumaczyć jako pozbawienie specjalnego stopnia wojskowego, stużbowego, kategorii zawodowej lub klasy kwalifikacyjnej. Ten rodzaj kary jest nieznany prawu polskiemu, ale w pewnym zakresie może pokrywać się ze środkiem karnym przewidzianym $\mathrm{w}$ art. 39 k.k., który przewiduje pozbawienie wykonywania określonego zawodu, lecz w Polsce nie jest on jednak odpowiednikiem omawianego ukraińskiego rodzaju kary.

Kara ta $\mathrm{w}$ prawie ukraińskim jest bezterminowa. Popełnienie przestępstw, za które jest ona wymierzana, hańbi bowiem wspomniane stopnie wojskowe i urzędnicze, dlatego ukraińska ustawa karna daje sądowi prawo dożywotniego ich pozbawienia. Wszystkich wymienionych przez prawodawcę: specialnogo zvannâ, rangu, čynu abo kvalifikacijnogo klasu może - zgodnie z ustawodawstwem Ukrainy - pozbawić wyłącznie sąd na podstawie st. 54 KKU. Kara przewidziana w st. 54 należy do tak zwanych specjalnych rodzajów kar i może być zastosowana wyłącznie w stosunku do osoby, która w momencie wyrokowania posiadała jeden ze stopni lub tytułów, nadany zgodnie z obowiązującą procedurą (Strilec' 2000, 213). Charakter tej kary jest zatem zrozumiały dla odbiorcy polskiego, jednakże problematyczne okazuje się tłumaczenie ukraińskich terminów zvannâ, ranga, čyn i kvalifikacijnyj klas na język polski.

Pierwszy termin - zvannâ - wskazuje na rodzaj kary pozbawienia stopnia wojskowego. Zgodnie z Terminologičnym slovnykom ukrä̈n'ko-pol's'kym, pol's'koukrä̈n'kym - pravo, finansy, ekonomika, torgivlâ (Âcenko 2004, 134) oznacza 'miano, tytuł, godność, stopień'. Zvannâ występują w Siłach Zbrojnych Ukrainy, w Służbie Bezpieczeństwa Ukrainy, w wojsku przygranicznym, wojsku wewnętrznym, wojsku obrony cywilnej Ukrainy, marynarki wojennej i innych, na przykład: kapitan, major, polkovnyk, general, których odpowiednikiem są w języku polskim stopnie wojskowe: kapitan, major, pótkownik, generat, przewidziane w art. 74. 1. Ustawy z dnia 21 listopada 1967 r. o powszechnym obowiązku obrony Rzeczypospolitej Polskiej (Dz. U. nr 241, poz. 2416).

Kolejnym terminem użytym do określenia omawianego rodzaju kary są tzw. rangy. Jak podaje Velykyj encyklopedyčnyj jurydyčnyj slovnyk (Šemšučenko 2007, 756), słowo ranga pochodzi od francuskiego rang czyli 'rząd, szereg' i oznacza 'stopień urzędniczy, który stanowi wskaźnik poziomu znaczenia funkcjonariuszy publicznych'. Terminologičnyj slovnyk ukrä̈ns'ko-pol's'kyj, pol's'ko-ukrä̈ns'kyj - pravo, finansy, ekonomika, torgivlâ (Âcenko 2004, 287) thumaczy ten termin jako 'rangę'. 'Ranga' z kolei w języku polskim oznacza '1. stopień służbowy w hierarchii wojskowej, 2. znaczenie, ważność czegoś lub kogoś' (Sobol 2003, 825). Wobec nieścisłości warto zbadać więc przepisy prawa Ukrainy w celu ustalenia właściwego znaczenia tego terminu.

Rangy ustala się w różnych służbach Ukrainy, więc w zależności od ich charakteru należałoby tłumaczyć to słowo na różne sposoby. Na przykład w organach 
spraw wewnętrznych Ukrainy ustala się takie rangi: major miliciï, pidpolkovnyk vnutrišn'ö̈ služby. Polska Ustawa z dnia 6 kwietnia 1990 r. o Policji (Dz.U. Nr 30 poz. 179) przewiduje $\mathrm{w}$ art. 47 ust. 1 stopnie policyjne: major milicji, podputkownik stużby wewnętrznej, analogiczne do wyżej wymienionych. W Polsce w latach 1944-1990, kiedy podobnie jak obecnie na Ukrainie działała milicja, nadawano stopnie milicji. Jednakże rangy przewidziano również w Służbie Podatkowej Ukrainy, na przykład: inspektor podatkovoï služby peršogo rangu, deržavnyj radnyk podatkovoï služby. Tymczasem ustawodawstwo polskie początku XX wieku przypisywało tak zwanej kategorii urzędniczej dwanaście różnych stopni stużbowych, przy czym stopniem najwyższym był stopień 1. Stopnie te zniesiono w 1933 roku, wprowadzając w ich miejsce dwanaście grup uposażenia zasadniczego (Serwis Służby Cywilnej). Obecnie w polskich urzędach przewiduje się stopnie stużbowe urzędników stużby cywilnej (Rozporządzenie Prezesa Rady Ministrów z dnia 16 stycznia 2007 r. w sprawie określenia stanowisk urzędniczych, wymaganych kwalifikacji zawodowych, stopni służbowych urzędników służby cywilnej, mnożników do ustalania wynagrodzenia oraz szczegółowych zasad ustalania i wypłacania innych świadczeń przysługujących członkom korpusu służby cywilnej (Dz.U. nr 12 poz. 79). Rangy przewidziane są także w służbie dyplomatycznej Ukrainy, na przykład: nadzvyčajnyj $i$ povnovažnyj posol, posol, radnyk peršogo klasu, których odpowiednikiem w polskiej dyplomacji są stopnie dyplomatyczne, na przykład: ambasador tytularny, radca - minister, I radca, radca, attaché (art. 8 Ustawy z dnia 27 lipca 2001 r. o służbie zagranicznej (Dz.U. nr 128 poz. 1403), nadawane członkom personelu dyplomatycznego przez Ministerstwo Spraw Zagranicznych państwa wysyłającego dyplomatów.

Wobec powyższego, tłumaczenie proponowane przez wspomniany słownik należy uznać za niewłaściwe. Autor słownika wpadł w tak zwaną ,pułapkę językową”, wynikająca $\mathrm{z}$ podobnego brzmienia terminu $\mathrm{W}$ języku ukraińskim i polskim. W tłumaczeniu trudno ująć jednak vijs'kove, special'ne zvannâ, rang, čyn i kvalifikacijnyj klas w jednym terminie polskim. Polski stopień stużbowy wydaje się spełniać tę rolę, stopniem służbowym może być bowiem funkcjonujący w języku polskim zarówno termin stopień milicji, jak i stopień dyplomatyczny.

Trudności przysparza również przetłumaczenie trzeciego terminu wskazanego przez ustawodawcę ukraińskiego - čyn. Terminu čyn nie notuje Terminologičnyj slovnyk ukraïns'ko-pol's'kyj, pol's'ko-ukraïns'kyj - pravo, finansy, ekonomika, torgivlâ. Należy więc sięgnąc do innych dostępnych na rynku słowników. Omawiany termin Pol's'koukraïns'kyj ta ukrä̈ns'ko-pol's'kyj slovnyk (Bačyns'kyj, Zadniprâna i Hotyns'ka 2006, 520), objaśnia jako ranga, stopień, natomiast Pol's'ko-ukrä̈ns'kyj ukraïns'ko-pol's'kyj slovnyk (Malec'ka i Landovs'ki, 2004, 812), objaśnia jako stanowisko. Tymczasem termin ten zgodnie z st. 47 Zakonu Ukrä̈ny «Pro prokuraturu» (VVR 1991, N 53, st. 793), nadawany jest na Ukrainie prokuratorom i śledczym organów prokuratury, pracownikom tak zwanych naukovo-navčal'nyh zakladiv, na przykład: deržavnyj radnyk ûstycï Ukraïny, deržavnyj radnyk ûstyciï I, II i III klasiv w zależności od zajmowanego stanowiska i stażu pracy. Ponieważ w ustawodawstwie Polski nie sposób odnaleźć odpowiednika tego terminu, należałoby użyć zwrotu oddającego sens i charakter danego tytułu, na przykład stopnie klasowe - omawiane stopnie posiadają bowiem klasy. Przykładowo, stopień państwowego radcy prawnego I, II i III klasy nadaje Prezydent 
Ukrainy, inne - nadawane są przez Prokuratora Generalnego Ukrainy (Nor 2002, 67). Omawiane stopnie nadaje się na Ukrainie również specjalistom sądów arbitrażowych (prócz sędziów). Ponieważ jednak w języku polskim przymiotnik klasowy kojarzy się z klasowością społeczeństwa, a poprzez zastosowanie terminu stopnie klasowe tłumacz mógłby narzucić błędną interpretację, bardziej trafnym terminem zdaje się być stopień zawodowy lub kategoria zawodowa.

Kolejny termin użyty przez ustawodawcę ukraińskiego w treści przepisu, przewidującego omawianą karę to kvalifikacijnyj klas. Terminologičnyj slovnyk ukraïns'kopol's'kyj, pol's'ko-ukrä̈ns'kyj - pravo, finansy, ekonomika, torgivlâ (Âcenko 2004, 161) nie notuje tego terminu, jednak pod pojęciem klas odnajdujemy odpowiedniki: klasa, kategoria. Ustawodawstwo polskie nie zna równoważnych tytułów urzędniczych - na Ukrainie kvalifikacijnyj klas jest nadawany sędziom wszelkich sądów, w tym również sędziom sądów arbitrażowych, a także biegłym sądowym. Należałoby zatem zachować ten termin w jego równoważnym brzmieniu: klasa kwalifikacyjna. Termin kategoria kwalifikacyjna jest również dopuszczalny.

Warto zauważyć, że autorzy wskazanych słowników ukraińsko-polskich nie dokonali dogłębnej analizy omawianych terminów. Z uwagi na fakt, że wszystkich wyżej wskazanych informacji nie sposób zawrzeć w tłumaczeniu omawianej kary, podane na wstępie do punktu II tłumaczenie jest w pełni uzasadnione.

\section{Pozbavlennâ prava obijmaty pevni posady abo zajmatysâ pevnoû diâl'nistû}

Termin pozbavlennâ prava obijmaty pevni posady abo zajmatysâ pevnoû diâl'nistû, $\mathrm{w}$ dosłownym tłumaczeniu pozbawienie prawa do zajmowania pewnych stanowisk lub prowadzenia pewnej działalności, zgodnie z st. $55 \S 2 \mathrm{KKU}$ jest podstawą wymierzenia kary przez sąd wobec ustalenia faktu, że podczas dokonania przestępstwa sprawca zajmował określone stanowisko lub prowadził określoną działalność, a popełnione przestępstwo miało charakter bezpośrednio związany $\mathrm{z}$ tym stanowiskiem lub działalnością, oraz że charakter popełnionego przestępstwa, dane o jego osobie i inne okoliczności świadczą o niecelowości dalszego zajmowania określonego stanowiska lub prowadzenia określonej działalności (Savčenko, Kuznecov i Štan'ko 2005, 401). Analogicznym środkiem karnym w prawie polskim jest zakaz zajmowania określonego stanowiska, wykonywania określonego zawodu lub prowadzenia określonej działalności gospodarczej przewidziany w art. 39 pkt. 2 k.k. Łatwo zauważyć, że ustawodawca polski ujął tę karę szerzej, pozbawiając sprawcę czynu zabronionego również prawa do wykonywania określonego zawodu. W celu nadania płynnego prawnego brzmienia terminu pozbavlennâ prava obijmaty pevni posady abo zajmatysâ pevnô̂ diâl'nistû w języku polskim warto przetłumaczyć go jako zakaz zajmowania określonego stanowiska lub prowadzenia określonej dziatalności. 


\section{Gromads'ki roboty}

Kara gromads'ki roboty, w tłumaczeniu dosłownym prace obywatelskie lub prace społeczne, została ustanowiona przepisem st. $56 \mathrm{KKU}$. Termin ten oznacza na Ukrainie wykonywanie przez skazanego w wolnym od pracy lub nauki czasie, w okresie wyznaczonym wyrokiem sądowym, bezpłatnych prac społecznie użytecznych, do których należą na przykład: sprzątanie ulic, remont dróg, budynków (Kuznecov, Strel'byc'kyj i Giževs'kyj 2005, 263). Rodzaj i charakter tej kary wyznaczają na Ukrainie organy samorządu terytorialnego. Karę tę wymierza się w granicach od sześćdziesięciu do dwustu czterdziestu godzin w wymiarze, który nie może przekroczyć czterech godzin dziennie. Zgodnie z przepisami prawa Ukrainy, omawianej kary nie można stosować w stosunku do osób z orzeczoną pierwszą lub drugą grupą inwalidzką, kobiet ciężarnych, emerytów, a także żołnierzy na służbie (Mel'nyk i Klymenko 2004, 352). Nieletnim sąd ukraiński może wymierzyć omawianą karę wyłącznie z zachowaniem wymogów stawianych przez st. $100 \S 1^{63}$ oraz st. $103^{64}$ KKU. Skazany na tę karę może opuścić terytorium Ukrainy wyłącznie za zgodą właściwego organu.

W ustawodawstwie polskim prace wykonywane na cele społeczne na podstawie Rozporządzenia Ministra Pracy i Polityki Społecznej z dnia 22 lipca 2011 r. w sprawie organizowania prac społecznie użytecznych (Dz.U. nr 155 poz. 921) są znane jedynie jako jeden ze sposobów wykonania kary ograniczenia wolności, a nie jako odrębny rodzaj kary. W Polsce prace społecznie użyteczne wykonuje się w odpowiednim zakładzie pracy, placówce służby zdrowia, opieki społecznej, w instytucji lub organizacji charytatywnej lub na rzecz społeczności lokalnej, według decyzji zawodowego kuratora sądowego po uprzednim wysłuchaniu skazanego (art. 57 § 1 k.k.w.). Wymiar czasu tej pracy ustalany jest przez sąd, po wysłuchaniu skazanego, w granicach od dwudziestu do czterdziestu godzin miesięcznie, zgodnie z art. $35 \S 1$ k.k. Ukraińska kara gromads'ki roboty odpowiada zatem polskiemu terminowi prace społecznie uzyteczne. Termin ten pozwoli polskiemu prawnikowi w zupełności zrozumieć charakter omawianej kary przewidzianej w ukraińskim ustawodawstwie.

\section{Vypravni roboty}

Vypravni roboty, w dosłownym thumaczeniu prace poprawcze - uregulowane zostały przez st. $57 \mathrm{KKU}$ i polegają na nałożeniu na skazanego obowiązku pracy w miejscu jego zatrudnienia (st. $41 \S 1 \mathrm{KVKU}$ ) na okres wskazany w wyroku sądu, a także na obowiązku systematycznego rejestrowania się w instytucji zwanej kryminal'no-vykonavča inspekciâ (st. $41 \S 6 \mathrm{KVKU}$ ). Ponadto, zgodnie z st. 42 § 1 i 42 § $4 \mathrm{KVKU}$, na skazanego nakłada się zakaz rozwiązania stosunku pracy z własnej woli i wyjazdu za granicę Ukrainy bez pozwolenia wyżej wspomnianej instytucji. Z kwoty wynagrodzenia skazanego przymusowo pobiera się comiesięcznie określoną kwotę na rzecz budżetu państwa w granicach od 10 do $20 \%$ wysokości wynagrodzenia. Prace poprawcze są wymierzane

\footnotetext{
${ }^{63}$ Zgodnie z przepisami prawa Ukrainy, prace społeczne mogą być orzeczone nieletniemu w wieku od 16 do 18 lat na okres od trzydziestu do stu dwudziestu godzin i podlegają wykonaniu w wolnym czasie od nauki lub głównej pracy. Czas wykonania danego rodzaju kary nie może przewyższać dwóch godzin na dzień.

${ }^{64}$ Przy wymierzaniu kary nieletniemu sąd bierze pod uwagę warunki życiowe i wychowania, wpływ dorosłych, stopień rozwoju i inne charakterystyczne cechy osoby nieletniego.
} 
przez sąd ukraiński w granicach od sześciu miesięcy do dwóch lat. W akcie postanova Plenumu Verhovnogo Sudu Ukrä̈ny vid 24 žovtnâ 2003 r. №7 «Pro praktyku pryznačennâ sudamy kryminal'nogo pokarannâ» (iz zminamy, vnesenymy zgidno z postanovamy Plenumu Verhovnogo Sudu Ukrä̈ny № 18 vid 10 grudnâ 2004 r., № 8 vid 12 červnâ 2009 r. ta № 11 vid 6 lystopada 2009 r.) zaznaczono w pkt. 12, że vypravni roboty wymierza się wyłącznie osobom pracującym w miejscu ich zatrudnienia (Šemšučenko 2007, 93). Zgodnie z przepisem st. 42 KVKU okres odbywania prac poprawczych wlicza się do stażu pracy. Prace poprawcze nie mogą być stosowane na Ukrainie $\mathrm{w}$ stosunku do kobiet ciężarnych, kobiet przebywających na urlopie macierzyńskim, osób niezdolnych do pracy, osób, które nie ukończyły 16 roku życia, emerytów, żołnierzy, pracowników państwowych, notariuszy, sędziów, prokuratorów i adwokatów (Šem'âkov i Hohlov 2006, 179).

Warto przypomnieć, iż uregulowanie polskiej kary ograniczenia wolności, wzorowane było na omawianej karze pracy poprawczej, przewidzianej w radzieckim prawie karnym, która przyjęła się również w ustawodawstwach innych państw socjalistycznych. W obowiązującym prawie karnym Polski odpowiednik ukraińskiej kary vypravni roboty jest jedynie jednym ze sposobów realizacji kary ograniczenia wolności i nie występuje samodzielnie jako odrębny rodzaj kary. W Polsce jednak zatrudnionemu, skazanemu na karę ograniczenia wolności, potrąca się z wynagrodzenia $10-25 \%$ na rzecz Skarbu Państwa, albo na cel społeczny wskazany przez sąd. W związku z brakiem terminu polskiego określającego omawianą karę, słusznym byłoby pozostawienie jej nazwy w dosłownym tłumaczeniu.

\section{Službovi obmežennâ dlâ vijjs'kovoslužbovciv}

Službovi obmežennâ dlâ vijs'kovoslužbovciv, czyli dosłownie ograniczenia stużbowe dla żotnierzy, przewidziane jako kara w st. $58 \mathrm{KKU}$, nie są znane polskiemu Kodeksowi karnemu zarówno w części ogólnej, jak i wojskowej. Kara ta jest wymierzana na Ukrainie w granicach od sześciu miesięcy do lat dwóch. Przy zastosowaniu tej kary skazanemu nie można powierzyć wyższego stanowiska, ani awansować go na wyższy stopień wojskowy. Okresu kary nie zalicza się do okresu służby, wymaganego do awansu na wyższy stopień, a w trakcie odbywania kary pobierana jest na rzecz budżetu państwa czesść wynagrodzenia skazanego, w granicach od 10 do 20 \% (Mel'nyk i Klymenko 2004, 370).

\section{Konfiskaciâ majna}

Konfiskaciâ majna, w dosłownym tłumaczeniu konfiskata mienia, regulowana st. 59 KKU, polega na przymusowym, bezpłatnym przekazaniu na rzecz budżetu państwa części lub całości mienia, które jest prywatną własnością skazanego i może być wymierzona za ciężkie i szczególnie ciężkie przestępstwo. Kara ta znana była w polskim prawie karnym jako kara dodatkowa konfiskaty mienia do roku 1990, orzekana w przypadku skazania za zbrodnie przeciwko podstawowym interesom politycznym lub gospodarczym państwa, zagarnięcie mienia społecznego znacznej wartości lub inną zbrodnię dokonaną $\mathrm{z}$ chęci zysku. Wobec powyższego tłumaczenie tego terminu nie budzi wątpliwości. 


\section{Arešt}

Arešt, w dosłownym tłumaczeniu areszt, jest uregulowany na Ukrainie przepisem st. 60 KKU. W przypadku tłumaczenia tego terminu łatwo o pomyłkę. W dostępnych na rynku słownikach, w tym również we wspominanym słowniku Terminologičnyj slovnyk ukrä̈ns'ko-pol's'kyj, pol's'ko-ukrä̈ns'kyj - pravo, finansy, ekonomika, torgivlâ (Âcenko 2004, 13), pod pojęciem ukraińskiego terminu arešt odnajdujemy bowiem polski odpowiednik: areszt, aresztowanie, zajęcie. Nie sposób jednak zgodzić się z takim tłumaczeniem w kontekście systemu kar kryminalnych. W ukraińskim prawie karnym areszt jest kara, natomiast w polskim prawie karnym tymczasowe aresztowanie (potocznie areszt) jest rodzajem środka zapobiegawczego, czyli instrumentem prawnym, służącym zamknięciu podejrzanemu lub oskarżonemu dróg wpływania na przebieg postępowania, w szczególności w drodze ucieczki, ukrywania się przed sądem i organami ścigania, zacierania śladów, nakłaniania świadków do zmiany ich zeznań itp., lub, w przypadku podejrzenia o popełnienie ciężkich przestępstw, w celu zapobieżenia popełnieniu kolejnych przestępstw. Z kolei odpowiednikiem polskiego środka zapobiegawczego w postaci aresztu, jest w prawie ukraińskim środek zapobiegawczy o nazwie trymannâ pid vartoû - w dosłownym tłumaczeniu przetrzymywanie pod warta (potocznie również nazywane na Ukrainie arešt). Jednakże areszt jest znany polskiemu ustawodawstwu jako kara, ale w prawie wykroczeń. Jego wymierzanie regulują przepisy art. 19, 26, 35, 38 i 42-44 Kodeksu wykroczeń (Ustawa z dnia 31 sierpnia 2011 r. o zmianie ustawy - Kodeks wykroczeń (Dz.U. nr 224 poz. 1340). Wobec powyższych niezgodności, warto zbadać charakter tej kary w prawie karnym Ukrainy.

Kara aresztu w ukraińskim prawie karnym jest wymierzana w granicach od jednego do sześciu miesięcy. Skazany odbywa ją w specjalnych tzw. areštnyh domah, zgodnie z st. 11, 15, $50 \mathrm{KVKU}$. Skazani na karę aresztu trzymani są w warunkach izolacji (st. $51 \S 1 \mathrm{KVKU}$ ) i nakłada się na nich ograniczenia charakterystyczne dla osób, które odbywają karę pozbawienia wolności (Gryŝuk 2006, 130). Nie może być zastosowana w stosunku do osoby, która nie ukończyła 16 lat, kobiet ciężarnych oraz kobiet, które mają dzieci do lat 7 (Mel'nyk i Klymenko 2004, 374). Nieletniemu w wieku od 16 do 18 lat omawiana kara może być wymierzona tylko z zachowaniem wymogów zawartych w st. $101^{65}$ i 103 KKU.

W związku z powyższym, z uwagi na izolacyjny charakter omawianej kary, zasadnym byłoby nazwanie jej krótkoterminowym pozbawieniem wolności. Natomiast słowniki prawnicze, obejmujące leksykę szerszą niż tylko dotycząca prawa karnego, powinny uściślić, że odpowiednikiem ukraińskiego terminu areštu jest polski areszt wyłącznie w prawie wykroczeń lub w znaczeniu środka zapobiegawczego w postaci tymczasowego aresztowania ${ }^{66}$.

\section{Obmežennâ voli}

Termin obmežennâ voli, przewidziany w st. 61 KKU czyli w tłumaczeniu dosłownym ograniczenie wolności, tak też tłumaczony przez dostępne na rynku słowniki ukraińsko-

\footnotetext{
${ }^{65} \mathrm{~W}$ takim przypadku areszt polega na umieszczeniu nieletniego, który w momencie uprawomocnienia wyroku ukończył 16 lat, w specjalnie przystosowanych warunkach izolacji na okres od piętnastu do czterdziestu pięciu dni.

${ }^{66}$ Ukraiński termin arešt oznacza również polski sekwestr, występuje również jako areszt domowy.
} 
polskie, może wprowadzić w błąd zarówno prawnika polskiego jak i tłumacza - nie posiada bowiem dokładnego odpowiednika w polskim prawie karnym. Na Ukrainie obmežennâ voli oznacza umieszczenie skazanego w zakładzie karnym typu otwartego, określanym tam mianem vypravnyj centr bez zupełnej izolacji od społeczeństwa, ale pod nadzorem, z obowiązkowym wykonywaniem pracy (st. 16, $56 \mathrm{KVKU}$ ).

Kara obmežennâ voli jest wymierzana $\mathrm{w}$ granicach od jednego do pięciu lat. Odbywanie tej kary jest zawsze powiązane z wykonywaniem pracy, dlatego w st. $61 \S 3$ KKU ukraiński ustawodawca zastrzegł, że nie może być ona wymierzana w stosunku do nieletniego, kobiet ciężarnych, kobiet, które mają dzieci do lat 14, emerytów, żołnierzy oraz osób z orzeczeniem pierwszej i drugiej grupy inwalidzkiej. Ponieważ charakter omawianej kary jest zbliżony do polskiej kary pozbawienia wolności, którą w Polsce skazany odbywa w zakładzie półotwartym na podstawie art. 92 k.k.w., należałoby w języku polskim określić ukraińską karę obmežennâ voli jako karę pozbawienia wolności w zakładzie pótotwartym z obowiazkowym wykonywaniem pracy.

\section{Trymannâ v dyscyplinarnomu batal'joni vijs'kovoslužbovciv}

Trymannâ $v$ dyscyplinarnomu batal'joni vijs'kovoslužbovciv $\mathrm{w}$ dosłownym tłumaczeniu przetrzymywanie żotnierza $w$ batalionie dyscyplinarnym (st. $62 \mathrm{KKU}$ ) nie jest znane polskiemu Kodeksowi karnemu, również w części wojskowej. Stosuje się ją wyłącznie w stosunku do żołnierzy służby terminowej. Kara ta polega na przymusowym umieszczeniu na okres od sześciu miesięcy do dwóch lat w szczególnej wojskowej jednostce - batalionie dyscyplinarnym, przeznaczonym do odbywania kary przez żołnierzy, którzy dopuścili się czynu zabronionego podczas odbywania służby. Zgodnie z st. $71 \S 6 \mathrm{KVKU}$ i Ukazom Prezydenta Ukraïny «Pro Položennâ pro dyscyplinarnyj batal'jon u Zbrojnyh Sylah Ukraïny» vid 5 kvitnâ 1994 roku N $139 / 94$ osoby, które odbywają karę w batalionie dyscyplinarnym, wykonują obowiązki i korzystają z praw, określonych przez ustawodawstwo ukraińskie, dla żołnierzy służby terminowej, z ograniczeniami przewidzianymi w st. $71-85 \mathrm{KVKU}^{67}$. Dopiero po odbyciu kary, skazani wracają do swojej jednostki w celu dalszego odbywania służby, dlatego też czas przebywania w batalionie dyscyplinarnym nie jest wliczany do okresu służby (Gryŝuk 2006, 132).

\section{Pozbavlennâ voli na pevnyj strok}

Pozbavlennâ voli na pevnyj strok, czyli pozbawienie wolności na czas określony (st. 63 KKU) jest rodzajem kary, zgodnie z którą skazanego izoluje się od społeczeństwa w drodze umieszczenia go w odpowiednim zakładzie karnym na okres orzeczony wyrokiem sądu. Karę tę odbywa się na Ukrainie w zakładach karnych typu zamkniętego, których rodzaj oraz tryb, zgodnie z st. $86 \mathrm{KVKU}$, określony jest przez Deržavnyj departament Ukraïny z pytan' vykonannâ pokaran'. Osoby pełnoletnie odbywają karę

\footnotetext{
${ }^{67}$ Opisują one $\mathrm{m}$. in. procedurę wykonania tej kary, tryb w batalionie dyscyplinarnym, odwiedziny i rozmowy telefoniczne skazanych, korespondencję listowną, krótkoterminowe przepustki, otrzymywanie przesyłek pocztowych, pracę i naukę skazanych, społecznie-wychowawczą pracę, środki zachęty dla skazanych, materialne i medyczne zabezpieczenie skazanych, zwolnienie od wykonania kary z powodu choroby.
} 
pozbawienia wolności w tzw. vypravnyh koloniâh ${ }^{68}$ (st. $18^{69}, 138$ do $140^{70} \mathrm{KVKU}$ ), natomiast osoby nieletnie w tzw. vyhovnyh koloniâh ${ }^{71}$ (st. $19^{72}, 143$ do $149^{73}$ KVKU). Pozbawienie wolności związane jest $\mathrm{z}$ istotnymi ograniczeniami dla skazanego, który nie tylko zostaje odizolowany od społeczeństwa, ale też pozbawia się go możliwości swobodnego przemieszczania się, wyboru rodzaju wykonywanej pracy, ogranicza się go w dysponowaniu swoim czasem, spotkaniach z rodziną i bliskimi (Gryŝuk 2006, 134). Podobne ograniczenia przewiduje polskie prawo karne wykonawcze. Na skazanego na karę pozbawienia wolności wywiera się pewien wpływ: przebywa on w warunkach narzuconego trybu, a w razie konieczności nakłada się na niego obowiązek nauki zawodu lub uzupełniania wiedzy ogólnej (rozdziały XVI do XIX KVKU oraz rozdział X k.k.w.).

Odpowiednikiem kary pozbavlennâ voli na pevnyj strok mogłaby być w polskim prawie karnym kara pozbawienia wolności lub kara 25 lat pozbawienia wolności, które również stanowią karę pozbawienia wolności na czas określony, gdyż przewidują granice czasowe tej kary. Sąd ukraiński wymierza jednak omawianą karę w granicach od 1 do 15 lat - jedynie w przypadku wyroku łącznego, zgodnie z st. $71 \S 2$ KKU oraz przy

\footnotetext{
${ }^{68}$ Odpowiednikiem tego terminu jest w prawie polskim zakład karny.

${ }^{69}$ Przepis ten przewiduje, że na Ukrainie skazani odbywają karę pozbawienia wolności na pewien okres lub karę dożywotniego pozbawienia wolności w vypravnyh koloniâh: Minimalnego stopnia bezpieczeństwa w złagodzonych warunkach - zostają tam umieszczone osoby, które zostały skazane po raz pierwszy do odbywania kary pozbawienia wolności za przestępstwo dokonane z nieostrożności, za przestępstwo niewielkiej lub średniej wagi, jak również osoby przeniesione z zakładu minimalnego stopnia bezpieczeństwa w warunkach ogólnych oraz zakładów średniego stopnia bezpieczeństwa, zgodnie z procedurą przewidzianą w KVKU, Minimalnego stopnia bezpieczeństwa $w$ warunkach ogólnych - zostają tam umieszczeni mężczyźni po raz pierwszy skazani do odbywania kary pozbawienia wolności za przestępstwa niewielkiej lub średniej wagi, kobiety, skazane za przestępstwo niewielkiej lub średniej wagi, ciężkie lub szczególnie ciężkie przestępstwa. W zakładzie tego typu mogą również odbywać karę skazani przeniesieni z zakładu wychowawczego, zgodnie z procedurą określoną w st. $147 \mathrm{KVKU}$, Średniego stopnia bezpieczeństwa - zostają tam umieszczone kobiety skazane do odbywania kary pozbawienia wolności, kobiety, którym karę śmierci (wskutek jej zniesienia) lub karę dożywotniego pozbawienia wolności zamieniono na karę pozbawienia wolności na czas określony, zgodnie z procedurą ułaskawienia lub amnestii, mężczyźni po raz pierwszy skazani na karę pozbawienia wolności za ciężkie lub szczególnie ciężkie przestępstwa, mężczyźni skazani za dokonanie umyślnego przestępstwa średniej wagi na karę pozbawienia wolności, skazani przeniesieni z,,zakładu maksymalnego stopnia bezpieczeństwa" zgodnie z procedurą postępowania KVKU, Maksymalnego stopnia bezpieczeństwa, w których umieszcza się mężczyzn, skazanych na karę dożywotniego pozbawienia wolności, mężczyzn, którym karę śmierci (wskutek jej zniesienia) zamieniono na karę dożywotniego pozbawienia wolności, mężczyzn, którym karę śmierci lub dożywotniego pozbawienia wolności zamieniono na karę pozbawienia wolności na określony czas, zgodnie z procedurą ułaskawienia lub amnestii, mężczyzn, skazanych za umyślne szczególnie ciężkie przestępstwo, mężczyzn, skazanych za dokonanie umyślnego ciężkiego lub szczególnie ciężkiego przestępstwa W okresie odbywania kary pozbawienia wolności, mężczyzn, przeniesionych z zakładu poprawczego średniego stopnia bezpieczeństwa, zgodnie z procedurą postępowania KVKU.

${ }_{70}$ Podane artykuły opisują prawa skazanych, odbywających karę w poszczególnych rodzajach zakładów poprawczych.

${ }_{71}^{71}$ Odpowiednikiem tego terminu jest w prawie polskim zakład poprawczy.

72 Vyhovni koloniï umożliwiają wykonanie w stosunku do nieletnich karę pozbawienia wolności na czas określony.

${ }^{73}$ Podane artykuły opisują prawa nieletnich, odbywających karę w poszczególnych zakładach poprawczych oraz nagrody za dobre sprawowanie, kary za naruszenie porządku w zakładzie oraz zasady ich przyznawania, zasady przeniesienia skazanego nieletniego do zakładu poprawczego oraz przetrzymywania go w zakładzie wychowawczym po osiagnnięciu 18 lat.
} 
zamianie kary dożywotniego pozbawienia wolności przez akt ułaskawienia ${ }^{74}$ (st. $87 \S 2$ $\mathrm{KKU}^{75}$ ) na okres nieprzekraczający 25 lat. Wobec powyższego w tłumaczeniu należy ująć tę karę terminem kara pozbawienia wolności.

\section{Dovične pozbavlennâ voli}

Kara dovične pozbavlennâ voli, czyli dosłownie kara dożywotne pozbawienie wolności (st. $64 \mathrm{KKU}$ ), tak jak w Polsce, jest najsurowszym rodzajem kary w prawie karnym Ukrainy, zgodnie z którym skazanych izoluje się od społeczeństwa droga przymusowego umieszczenia ich w odpowiednich vypravnyh koloniâh tzw. maksymalnego stopnia bezpieczeństwa (st. $18 \S 2$ i $150 \S 1$ KVKU) bez oznaczenia okresu odbywania tej kary (Gončarenko 2004, 178). W sankcjach przewidzianych wprost w części szczególnej KKU kara pozbawienia wolności na określony czas jest alternatywą dla kary dożywotniego pozbawienia wolności. Dlatego też sąd, który orzekł karę dożywotniego pozbawienia wolności, zobowiązany jest podać w uzasadnieniu wyroku okoliczności, które świadczą o celowości zastosowania tej kary w stosunku do konkretnego skazanego (Postanova Plenumu Verhovnogo Sudu Ukraïny vid 24 žovtnâ 2003 roku N 7, p. 12). Zgodnie z st. $64 \S 2$ KKU kara dożywotniego pozbawienia wolności nie może być wymierzona na Ukrainie w stosunku do osób, które popełniły przestępstwo przed ukończeniem 18 lat lub po ukończeniu 65 lat, kobiet, które były ciężarne w czasie popełnienia przestępstwa lub wymierzania kary przez sąd. Skazani na karę dożywotniego pozbawienia wolności nie podlegają zwolnieniu z tej kary ${ }^{76}$. Wobec omówionych podobieństw pomiędzy ukraińską karą dovične pozbavlennâ voli i polską kara dożywotniego pozbawienia wolności, tłumaczenie tego ukraińskiego terminu na język polski nie powoduje trudności.

\section{Podsumowanie}

Na podstawie dokonanych badań należy stwierdzić, że tłumaczenie ukraińskich terminów prawnych, w tym rodzajów kar, jest bardzo problematyczne. Zastosowanie przez autora szerokiego wachlarza metod badawczych, w tym dogmatyczno prawnej, komparatystycznej i historycznej, pozwoliło na pełne, a jednocześnie zwięzłe, zbadanie znaczenia omawianych terminów oraz zaproponowanie ich polskich ekwiwalentów. Pośród dwunastu, przewidzianych przez prawo karne Ukrainy kar, tłumaczenie jedynie kilku nie wzbudziło wątpliwości, a dostępne słowniki ukraińsko-polskie przewidują prawidłowe ich ekwiwalenty. Wśród nich można wymienić grzywnę, konfiskatę mienia i karę dożywotniego pozbawienia wolności. Przy czym konfiskata mienia, choć nie jest przewidywana przez obowiązujące prawo polskie, jest znana poprzednio obowiązującej ustawie karnej. Jednakże tłumaczenie nazw większości z rodzajów kar, przewidzianych w prawie karnym Ukrainy, powoduje znaczne trudności. Również rynek wydawniczy

\footnotetext{
${ }^{74}$ Zgodnie z ustawodawstwem ukraińskim na podstawie aktu ułaskawienia skazany może być całkowicie lub w części zwolniony od wykonania kary zasadniczej i dodatkowej. Możliwa jest również zamiana wymierzonej kary na łagodniejszą. Ułaskawienia dokonuje Prezydent Ukrainy w stosunku do konkretnie wyznaczonej osoby.

75 Poprzez akt łaski wymierzona kara dożywotniego pozbawienia wolności może być zamieniona na karę pozbawienia wolności na określony czas.

${ }^{76}$ Wyłącznie akt ułaskawienia (st. 87 § 2 KKU) może zamienić tę karę na karę pozbawienia wolności na określony czas, jednak nie krótszy niż 25 lat. Wniosek o ułaskawienie może być złożony dopiero po odbyciu przynajmniej 15 lat kary dożywotniego pozbawienia wolności .
} 
oferuje znikomą ilość słowników specjalistycznych, a te, dostępne, jak wyżej wykazano, posiadają liczne nieścisłości. Znacznym utrudnieniem prawidłowego przekładu jest, wbrew pozorom, pokrewieństwo języka ukraińskiego i polskiego, powodujące liczne „pułapki językowe”. Warto tutaj wymienić praktykowane tłumaczenie kary areštu jako aresztu czy obmežennâ voli jako ograniczenia wolności. Inne, jak prace spotecznie użyteczne, są znane prawu polskiemu, ale funkcjonują w odmiennym znaczeniu. Niektóre rodzaje kar natomiast nie są nieznane prawu polskiemu, tj. službovi obmežennâ dlâ vijs'kovoslužbovciv czy pozbavlennâ vijs'kovogo, special'nogo zvannâ, rangu, čynu abo kvalifikacijnogo klasu - te należą do grupy terminów wymagających szerokich badań komparatystycznych i największego wysiłku tłumacza. Brak wiedzy prawniczej lub przeprowadzenia gruntownych badań porównawczych, a co za tym idzie niewłaściwe zrozumienie danego terminu może prowadzić bowiem do licznych pomyłek i nieścisłości w tłumaczeniach, a te do nieporozumień pomiędzy organami, nieprawidłowego sporządzenia odpowiedzi na wniosek o udzielenie pomocy prawnej czy niewykonania obowiązków wynikających z umowy międzynarodowej o pomocy prawnej, a także innych poważnych skutków.

W związku z powyższym warto zaznaczyć, że pomimo rosnącego zapotrzebowania na tłumaczenia prawne $\mathrm{i}$ prawnicze $\mathrm{w}$ zakresie języka ukraińskiego, problematyce przekładu dla tłumaczy języka ukraińskiego, poświęcono niewiele prac naukowych. Wprowadzenie odpowiednich zajęć na studiach filologicznych, obejmujących podstawy prawa lub elementy prawa dla tłumaczy, chociażby $\mathrm{w}$ zakresie prawa rodzimego, umożliwiłoby przyszłym tłumaczom samodzielne badanie systemu prawa polskiego i obcego, a co za tym idzie wykonywanie bezbłędnych tłumaczeń nawet przy braku innych pomocy naukowych jak słowniki prawnicze. Warto również aktywizować, zarówno praktyków jak i teoretyków, do opracowywania zagadnień problematycznych, w szczególności w zakresie tych mniej popularnych języków, w celu ich publikacji w dostępnych na rynku czasopismach dla tłumaczy. 


\section{Bibliografia}

Gryŝuk, V. K. 2006. Kryminal'ne Pravo Ukraïny - zagal'na častyna, Kyïv: Vydavnyčyj Dim „In Üre".

Bažanov, M. I. (red.) 2005. Kryminal'ne Pravo Ukrä̈ny - zagal'na častyna. Kyïv - Harkiv: Ûrinkon Inter - Pravo.

Mel'nyk, M. I. (red.) 2004. Kryminal'ne Pravo Ukraïny (zagal'na častyna). Kyïv: Ûrydyčna dumka.

Kuznecov, V. O. i Strel'byc'kyj M. P. i Giževs'kyj V. K. 2005. Kryminal'ne Pravo Ukraïny zagal'na i osoblyva častyna. Kyïv: Istyna.

Mel'nyk, M. I. (red.) 2007. Naukovo - praktyčnyj komentar Kryminal'nogo kodeksu Ukraïny. Kyïv: Ûrydyčna dumka.

Andrušk, P. P. (red.) 2009. Naukovo - praktyčnyj komentar do Kryminal'nogo kodeksu Ukraïny v dvoh tomah. Kÿ̈v: Kannon A.S.K.

Nor, V. T. (red.) 2002. Prokurors'kyj naglâd v Ukraïni, L'viv: Triada plûs.

Savčenko, A. V. i Kuznecov V. V. i Štan'ko O. F. 2005. Sučasne kryminal'ne pravo Ukrä̈n, Kyïv: Palyvoda A.V.

Selec'kyj, S. I. 2007. Kryminal'ne Pravo Ukraïny - zagal'na častyna, Kyïv: CUL.

Šem'âkov, O. P. i Hohlova I. V. 2006. Kryminal'ne Pravo Ukraïny - zagal'na častyna, Kyïv: CNL.

Havranûk, M. I. 2004. Dovidnyk z osoblyvoï častyny kryminal'nogo kodeksu Ukrä̈ny. Kyïv: Istyna.

\section{Akty prawne}

Rozporządzenie Ministra Pracy i Polityki Społecznej z dnia 22 lipca 2011 r. w sprawie organizowania prac społecznie użytecznych (Dz.U. nr 155 poz. 921).

Rozporządzenie Prezesa Rady Ministrów z dnia 16 stycznia 2007 r. w sprawie określenia stanowisk urzędniczych, wymaganych kwalifikacji zawodowych, stopni służbowych urzędników służby cywilnej, mnożników do ustalania wynagrodzenia oraz szczegółowych zasad ustalania i wypłacania innych świadczeń przysługujących członkom korpusu służby cywilnej (Dz. U. nr 12, poz. 79).

Ustawa z dnia 21 listopada 1967 r. o powszechnym obowiązku obrony Rzeczypospolitej Polskiej (Dz. U. nr 241, poz. 2416).

Ustawa z dnia 27 lipca 2001 r. o służbie zagranicznej (Dz.U. nr 128, poz. 1403).

Ustawa z dnia 31 sierpnia 2011 r. o zmianie ustawy - Kodeks wykroczeń (Dz.U. nr 224 poz. 1340).

Ustawa z dnia 6 czerwca 1997 r. Kodeks karny (Dz.U. nr 88 poz. 553).

Ustawa z dnia 6 czerwca 1997 r. Kodeks karny wykonawczy (Dz.U. nr 90 poz. 557).

Ustawa z dnia 6 kwietnia 1990 r. o Policji (Dz. U. Nr 30, poz. 179).

Zakon Ukraïny «Pro vijs'kovyj obov'âzok i vijs'kovu službu» (VVR 1992, N 27, st. 385).

Zakon Ukraïny «Pro deržavnu službu» vid 16 grudnâ 1993 r. (VVR 1993, N 52, st. 490).

Zakon Ukraïny «Pro prokuraturu» (VVR 1991, N 53, st. 793).

Zakonu Ukraïny «Pro prokuraturu» (VVR 1991, N 53, st. 793).

Kryminal'nyj kodeks Ukraïny (VVR 2001, N 25-26, st. 131). 
Kryminal'no-vykonavčyj kodeks Ukraïny (VVR 2004, N 3-4, st. 21).

Postanova Plenumu Verhovnogo Sudu Ukraïny vid 24 žovtnâ 2003 r. №7 «Pro praktyku pryznačennâ sudamy kryminal'nogo pokarannâ» (iz zminamy, vnesenymy zgidno z postanovamy Plenumu Verhovnogo Sudu Ukraïny № 18 vid 10 grudnâ 2004 r., № 8 vid 12 červnâ 2009 r. ta № 11 vid 6 lystopada 2009 r.).

Ukaz Prezydenta Ukraïny «Pro Položennâ pro dyscyplinarnyj batal'jon u Zbrojnyh Sylah Ukraïny» vid 5 kvitnâ 1994 roku N 139/94.

\section{Słowniki}

Domagalski, Stanisław. 2008. Wielki słownik polsko-ukraiński, ukraińsko-polski z rozszerzona terminologia biznesu. Warszawa: Wydawnictwo Rea.

Iwczenko, Anatol. 2003. Stownik ukraińsko-polski. Lublin: UMCS.

Jurkowski, Marian i Nazaruk Bazyli. 1998. Mały słownik ukraińsko-polski polsko-ukraiński. Warszawa: WSiP.

Sobol, Elżbieta (ed.) 2003. Nowy stownik języka polskiego, Warszawa: PWN.

Bačyns'kyj, D. V. i Zadniprâna A. B. i Hotyns'ka M. M. 2006. Pol's'ko-ukrä̈ns'kyj ta ukraïns'ko-pol's'kyj slovnyk. Kyïv: Čumac'kyj Šlâh.

Gončarenko, V. G. (red.) 2004. Ûrydyčni terminy. Tlumačnyj slovnyk. Kyïv: Lybid'.

Malec'ka, A, Landovs'ki Z. 2004. Pol's'ko-ukraüns'kyj ukrä̈ns'ko-pol's'kyj slovnyk, Kyïv: Irpin': VTF «Perun».

Riger, Â., Dems'ka-Kul'čyc'ka O. 2007. Ukraïns'ko-pol's'kyj tematyčnyj slovnyk. L'viv: Vydavnyctvo UKU.

Strilec', N. (red.) 2000. Slovnyk zakonodavčyh terminiv. Kyïv: Osnova.

Šemšučenko, Û. S. (red.) 2007. Velykyj encyklopedyčnyj jurydyčnyj slovnyk. Kyïv: «Ûrydyčna dumka».

Âcenko, I. S. (red.) 2004. Terminologičnyj slovnyk ukrä̈ns'ko-pol's'kyj, pol's'ko-ukrä̈ns'kyjpravo, finansy, ekonomika, torgivlâ. Kyïv: «Škola».

\section{Strony www:}

Serwis Służby Cywilnej http://www.dsc.kprm.gov.pl/strona.php?id=32\&id2=20

(data dostępu: 26 czerwca 2011 r., godz. 13:30). 